\title{
Community Empowerment in Development in Sakita Village, Bungku Tengah District, Morowali Regency
}

\author{
Raehani $^{1}$, Slamet Riadi ${ }^{2}$, Muhammad Ahsan Samad ${ }^{2}$ \\ 1,2,3 Universitas Tadulako, Palu \\ E-mail: raehani287@gmail.com
}

(Received: January-2019; Reviewed: February -2019; Accepted: March-2019;

Avalaibel Online: March 2019; Published: March -2019)

(7) (\$) This is an open access article distributed under the Creative Commons Attribution License CC-BY-NC-4.0 @2019 by author (https://creativecommons.org/licenses/by-nc/4.0/)

\begin{abstract}
This study aims to determine the process of community empowerment in development in Sakita Village, Bungku Tengah District, Morowali Regency. This study uses descriptive qualitative research type. This study uses theory (Elliot, 1996) to find out the stages in the process of community empowerment, there are 3 aspects that is, the welfare approach, the development approach and the empowerment approach. Data collection techniques are carried out through library research and field research. Which includes interview observation and documentation. There are 3 stages of qualitative data analysis namely data condensation, data presentation and conclusion drawing. Based on the research results obtained, it can be concluded that the quality of the welfare approach, development approach, and community empowerment approach in Sakita village, Bungku Tengah District, Morowali Regency have been implemented well. Although there are still many things that need to be improved by the village government together with the community.
\end{abstract}

Keywords: Empowerment; community; village development

\section{INTRODUCTION}

Nature management for the progress of the nation is related to development management. Even though we already have a fairly good development management, it is not yet perfect. There are various weaknesses in development management, such as planning, implementation, institutional, human resources (HR), inter-institutional synergy, public / private participation, budget management, information technology utilization, supervision, development control, and so on.

Rural development has an important role in the context of national development because it covers the largest share of national territory (Gani, 2015; Kadji, 2015; Lelo, Pandie, \& Tamunu, 2016; Prasodjo, 2016). Therefore, the development of rural communities must continue to be improved through the development of human resource capabilities in rural areas 
so that their creativity and activities can be further developed and environmental awareness increasingly high.

Community participation in development can be said to be a necessity (Fitriansah, 2012; Mubarak, 2010; Rahayu \& Budi, 2013; Wahyuningrum, 2014), but it cannot be denied that due to the backward condition of some members of the community both economic and educational backwardness causes a lack of enthusiasm the community to participate in carrying out the development planning process, if we look far ahead that in fact development will only succeed if it is supported by the community in implementing the development program both at the time of planning up to the implementation of the development program.

According to (Elliot, 1996) the process of community empowerment can be done in three approaches namely the welfare approach, the development approach, and the empowerment approach. The welfare approach in the village of Sakita is still not taken seriously by the village government, this can be seen from the lack of utilization of three sectors that have the potential to improve the welfare of the village community, namely the plantation, livestock, and tourism sectors that have not been well managed.

According to Mubyarto (2000: 263) empowerment is an effort to build power (the community) by encouraging, motivating and raising awareness of its potential and trying to develop it. Then Chatarina Rusmiyati (2011: 16) states that empowerment is as follows: "Empowerment is a way that people, organizations and communities are directed to be able to master their lives or empowerment is considered a process of making people strong enough to participate in events and institutions that affect his life. "Meanwhile according to (Amanah, 2010; Sulistyani \& Wulandari, 2017; Ulumiyah, Gani, \& Mindarti, 2013) empowerment can be interpreted as a process towards empowering or a process of giving power / strength / ability, and those who have power to those who have power. no or less defenseless. In terms of seeking empowerment in the community according to (Kartasasmita, 1996) can be seen from three sides, namely: settlement (enabling), strengthening (empowering) and protecting (protecting).

(Azis, 2005) detailing the stages that should be passed in conducting empowerment. First, helping the community in empowering. Second, do an analysis (study) of the problem independently (participatively). Third, determine the priority scale of the problem, in the sense of sorting and selecting each of the most pressing problems to be solved. Fourth, look for a solution to the problem being faced. Fifth, implement concrete actions to solve the problem that is being faced. Sixth, evaluate the whole set and process of empowerment to assess the extent of success and failure.

Working conditions and welfare of the Sakita village community which is still far from the word prosperity is a complex problem and needs to be planned, measured and efficient. Sakita village government together with the community needs to improve their competence and create opportunities for prosperity by utilizing the potential of the village they have. One of the efforts made by the government is to increase the participation of village communities by creating national programs, one of which is the village community empowerment program. Empowerment can be concluded is an effort to mobilize the potential that exists in the community in a practical and productive way to achieve goals by providing power and strength to carry out the tasks or targets achieved (Andriyani, Martono, \& Muhamad, 2014; Noor, 2011; Sudaryanto, Ragimun, \& Wijayanti , 2014; Widayanti, 2012)

\section{METHOD}

This type of research is a qualitative descriptive study. The types of data used are primary data and secondary data. Data collection techniques used are observation, interviews, and 
documentation. Data analysis consists of data collection, data condensation, data presentation and drawing conclusions.

\section{RESULT AND DISCUSSION}

Community empowerment is a process in which the community, especially those who are resource-poor, are supported in order to be able to independently improve their welfare. In community empowerment, the community is the actor and determinant of development.

\section{Welfare Approach}

Based on the results of the study, when viewed from the welfare approach it can be concluded that the welfare level of the Sakita village community is good enough. Although there are some people who say that the level of welfare of the Sakita village community has not been evenly distributed, efforts to improve the welfare of the community are still carried out by village officials.

\section{Development Approach}

Based on the results of the study, when viewed from the development approach in the village of Sakita is quite good, although there are still complaints from the community who feel they have not been empowered in terms of development and lack of socialization or information obtained in terms of village development.

\section{Empowerment Approach}

Based on the results of the study, when viewed from the empowerment approach to the community is still lacking, only a few communities can directly feel the empowerment that has been sought by the village government.

\section{Discussion}

The welfare approach is to work together with the community to help them to improve their dignity as human beings. Empowerment always aims to solve the problems of the community not to achieve the goals of outsiders or authorities. The development approach is a community empowerment activity that must be guaranteed its sustainability. Therefore, community empowerment must not create dependency but must be able to prepare the community because the community as the recipient of the benefits so that one day they will be able to independently to continue community empowerment activities as a process of sustainable development. The empowerment approach is that empowerment must directly involve or even be implemented by the community that is the beneficiary. Involving people who will receive benefits, has several objectives namely to make the assistance effective because it suits their wants and abilities and needs. In addition, at the same time increasing community empowerment with experience in designing, implementing, managing, and taking responsibility for efforts to improve themselves and the economy. 


\section{CONCLUSION}

Based on the results of the research that the researchers got in the field and direct interviews with the Regional Secretary, the government, staff, the village secretary and the Kasimbar community in Parigi Moutong district, the researcher drew the conclusion that the process of archival management at the Kasimbar sub-district office had run well when viewed in terms of planning, organizing and monitoring. . But in terms of implementation it can be seen that the management of archives that are carried out is still not good due to the lack of knowledge possessed by employees about records management.

\section{REFERENCES}

Amanah, S. (2010). Peran komunikasi pembangunan dalam pemberdayaan masyarakat pesisir. Komunikasi Pembangunan.

Andriyani, A. A. I., Martono, E., \& Muhamad. (2014). Pemberdayaan Masyarakat melalui Pengembangan Desa Wisata dan Implikasinya terhadap Ketahanan Sosial Budaya. Jurnal Ketahanan Nasional. https://doi.org/2527-9688

Azis, M. A. (2005). Pendekatan Sosiokultural dalam Pemberdayaan Masyarakat. Yogyakarta: Pustaka Pesantren.

Elliot, J. . (1996). An Introduction to Sustainable Development: The Developing world. London and Newyork: Routledge.

Fitriansah, H. (2012). Keberlanjutan Pengelolaan Lingkungan Pesisir Melalui Pemberdayaan Masyarakat di Desa Kwala Lama Kabupaten Serdang Bedagai. JURNAL PEMBANGUNAN WILAYAH \& KOTA. https://doi.org/10.14710/pwk.v8i4.6492

Gani, F. S. (2015). Tahapan Partisipasi Masyarakat Dalam Program Pembangunan Infrastruktur Perdesaan (PPIP) Di Desa Dungaliyo Kecamatan Dungaliyo Kabupaten Gorontalo. Jurnal Ilmiah Ilmu Administrasi Publik: Jurnal Pemikiran dan Penelitian Administrasi Publik, 5(1), 9-19.

Ismail, A., Sulur, A. H., Akib, H., \& Salam, R. (2016). Snapshot of Society Social-Economic Welfare based on Human Development Index in Polewali Mandar Regency, Indonesia. International Conference on Public Organization VI (ICONPO VI), 847-858. Thammsat University, Tha Prachan Campus.

Kadji, J. (2015). Pembangunan Masyarakat Sebagai Upaya Dalam Rangka Penanggulangan Kemiskinan Di Desa Leboto. Jurnal Ilmiah Ilmu Administrasi Publik: Jurnal Pemikiran dan Penelitian Administrasi Publik, 5(1), 31-37.

Kartasasmita, G. (1996). Pembangunan untuk rakyat: memadukan pertumbuhan dan pemerataan. Economic development--Indonesia; Economic policy; Economic conditions1945.

Lelo, L., Pandie, D., \& Tamunu, L. (2016). Implementasi Kebijakan Pembangunan Kelembagaan Pemerintah Kecamatan Sebagai Perangkat Daerah (Studi Di Kota Kupang Dan Kabupaten Sikka). Jurnal Ilmiah Ilmu Administrasi Publik: Jurnal Pemikiran dan Penelitian Administrasi Publik, 6(1), 1-10.

Mubarak, Z. (2010). Evaluasi Pemberdayaan Masyarakat Ditinjau dari Proses Pengembangan 
Kapasitas dapa Kegiatan PNPM Mandiri Perkotaan. Thesis Magister Teknik Pembangunan Wilayah dan Kota UNDIP, Semarang.

Noor, M. (2011). Pemberdayaan Masyarakat. Jurnal Ilmiah CIVIS. https://doi.org/10.2307/257670.Poerwanto.

Prasodjo, T. (2016). Strategi Pembangunan Kualitas Manusia: Suatu Perspektif Administrasi Publik. Jurnal Ilmiah Ilmu Administrasi Publik: Jurnal Pemikiran dan Penelitian Administrasi Publik, 6(2), 47-54.

Rahayu, M., \& Budi, A. (2013). Pembangunan Perekonomian Nasional Melalui Pemberdayaan Masyarakat Desa. Jakarta, www. kelembagaandas. wordpress.

Sudaryanto, Ragimun, \& Wijayanti, R. R. (2014). Strategi Pemberdayaan UMKM Menghadapi Pasar Bebas Asean. Www.Kemenkeu.Go.Id.

Sulistyani, A. T., \& Wulandari, Y. (2017). Proses Pemberdayaan Masyarakat Desa Sitimulyo Kecamatan Piyungan Kabupaten Bantul Dalam Pembentukan Kelompok Pengelola Sampah Mandiri (KPSM). Jurnal Pengabdian kepada Masyarakat (Indonesian Journal of Community Engagement). https://doi.org/10.22146/jpkm.27024

Ulumiyah, I., Gani, A. J. G., \& Mindarti, L. I. (2013). Peran Pemerintah Desa dalam Memberdayakan Masyarakat Desa (Studi pada Desa Sumberpasir Kecamatan Pakis Kabupaten Malang). Jurnal Administrasi Publik.

Wahyuningrum, Y. (2014). Pengaruh Program Corporate Social Responsibility Terhadap Peningkatan Pemberdayaan Masyarakat (Studi Pada Implementasi CSR PT. Amerta Indah Otsuka Desa Pacarkeling Kecamatan Kejayan Kabupaten Pasuruan). Jurnal Administrasi Publik Mahasiswa Universitas Brawijaya.

Widayanti, S. (2012). Pemberdayaan Masyarakat: Pendekatan Teoritis. In Ilmu Kesejahteraan Sosial. 
168 | Pinisi Discretion Review

Volume 2, Issue 2, March, 2019 Page. 163- 168 